\title{
Genetic polymorphism at RAPD loci in spring turnip rape (Brassica rapa ssp. oleifera)
}

\author{
Pirjo TanhuanpäÄ, Johanna VilkKi, Juha VilkKI and Seppo PUlli \\ TanhuanPäÄ, P.K., Vil.kKı, H.J., Vil.kKı, J.P. \& Pull.ı, S.K. 1993. Genetic poly- \\ morphism at RAPD loci in spring turnip rape (Brassica rapa ssp. oleifera). Agric. \\ Sci. Finl. 2: 303-310. (Agric. Res. Centre of Finland, Inst. of Plant Breed., FIN-31600 \\ Jokioinen, Finland.)

\begin{abstract}
In this study we analyzed polymorphism at RAPD loci in an outbreeding species, spring turnip rape. The reproducibility of individual RAPD patterns was high when the DNA templates were of equal quality and quantity. It was possible to use both a rapid DNA extraction method and DNA extracted from a combined sample of ten individuals without losing any of the major fragments. When different cultivars were compared for RAPD pattern, most polymorphic loci exhibited differences only in allele frequency. However, we also found fragments which were amplified only from certain cultivars. It was concluded that RAPD markers provide a fast and reliable method for analyzing individuals and cultivars of turnip rape.
\end{abstract}

Key words: RAPD markers, PCR, cultivar identification

\section{Introduction}

Polymorphism is expressed at different taxonomic levels ranging from individuals to cultivars and species, and is exploited widely in plant breeding. Firstly, variation among individuals can be used to construct genetic maps. Secondly, recognition of polymorphism in cultivars is important for patent questions, protection of breeder's rights and in quality control of seeds. Further, genetic relationships can be determined between cultivars, and also between species.

Analyzing variation in morphological characters is laborious, unreliable and dependent on the environment. These disadvantages can be avoided by using biochemical variation, e.g. isozymes (ARUS et al. 1982) or electrophoretic patterns of storage proteins (GUPTA and RÖBBELEN 1986, ROININEN et al. 1992). However, biochemical markers can reveal only a limited amount of polymorphism among closely related genotypes.
Extensive polymorphism is detected with DNAbased procedures, e.g. by RFLP (Restriction Fragment Length Polymorphism) and RAPD (Random Amplified Polymorphic DNA) methods. Compared to the frequently used RFLP assay the recently developed RAPD method (WILLIAMS et al. 1990, WELSH and McClelland 1990) is technically simple, non-radioactive, rapid and requires only small amounts of sample DNA, but is still capable of detecting extensive polymorphism. The RAPD method is based on the amplification of random DNA fragments in the polymerase chain reaction (PCR). The fragments are separated by electrophoresis, and their number and size depend on the position of sites in the template DNA homologous to the primer sequence used. A RAPD pattern or profile consists of all the DNA fragments amplified, and polymorphic fragments can be used as markers.

Besides the excellent features of the RAPD method, it also has some disadvantages. Firstly, the 
exact nature of the polymorphism is not known; it may be due to nucleotide changes in the DNA sequence of the primer binding site or to structural alterations (WILliams et al. 1990). Secondly, RAPD markers are dominant (absence of a fragment cannot be detected in a heterozygote) and therefore RAPDs are less informative than the mostly codominant RFLPs. On the other hand, this loss of information is compensated by the ability of one RAPD primer to generate a number of different markers. Finally, doubt has been raised about the reproducibility of RAPD patterns, at least for some fragments among separate runs or between laboratories (DEvos and GALE 1992, Koller et al. 1993, TINKER et al. 1993).

RAPDs have so far successfully been used e.g. for identifying species (QUIROS et al. 1991), inbred cultivars (HE et al. 1992, HU and QUIROS 1991, KRESOVICH et al. 1992) and somatic hybrids (XU et al. 1993). The extent of genetic polymorphism is quite different in out- and inbreeding populations. Outbreeding populations are genetically diverse, and therefore RFLPs should be more suitable than RAPDs for analyzing their variation, because RFLPs can identify multiple alleles at each locus. Nevertheless, we preferred RAPDs because of their excellent features.

We have tested the possibility to use RAPD markers in estimating genetic polymorphism in spring turnip rape (Brassica rapa ssp. oleifera) which is the most important oilseed crop cultivated in Finland. Our long-term goal is to construct a gene map of spring turnip rape which could be used to facilitate selection in breeding programs. Therefore, various aspects of the repeatability of RAPD markers were studied. One objective of the research reported here was to study whether cultivar identification is possible for an outbreeding species.

\section{Material and methods}

\section{Plant material}

Three major spring turnip rape varieties cultivated in Finland ('Valtti', Sv3232 = 'Kova' and Jo4003 = 'Kulta') were screened for differences in their
RAPD patterns. 'Kulta' is a new cultivar from Jokioinen, derived from the cross 'Valtti' $\mathrm{x}$ 'Kova' by recurrent phenotypic selection for low glucosinolate level and high yield. DNA was extracted from about 50 greenhouse-grown individuals of each cultivar separately as well as from pooled samples which consisted of equal amounts of leaf tissue from five different plants. The combined sample of a cultivar was made by uniting two pooled samples (= 10 different individuals). In addition, combined samples of leaves from these three cultivars were collected from the field during two subsequent summers and combined samples of ten more cultivars or lines in the summer 1992.

Two different DNA extraction methods were used, and the DNA concentrations were estimated by spectrophotometry (GeneQuant, Pharmacia). Large-scale DNA isolations (modified DELLAPORTA et al. 1983) were made from approximately $1.5 \mathrm{~g}$ of fresh leaves. Precipitated DNA was treated with RNase A (to $0.5 \mathrm{mg} / \mathrm{ml}$ ) and proteinase $\mathrm{K}$ (to $2 \mathrm{mg} / \mathrm{ml}$ ) at $65^{\circ} \mathrm{C}$ for $30 \mathrm{~min}$ each, and further purified with one phenol and two chloroform extractions. Finally, the DNA was reprecipitated with isopropanol, washed with $70 \%$ ethanol and dissolved in $100-200 \mu \mathrm{l}$ of TE $(10 \mathrm{mM}$ Tris, $1 \mathrm{mM}$ EDTA, pH 8).

In small-scale DNA isolations (modified EDWARDS et al. 1991), leaf tissue was collected using the lid of an Eppendorf tube. DNA was macerated with a grinder and $400 \mu \mathrm{l}$ of extraction buffer (200 mM Tris- $\mathrm{HCl}$ pH 7.5, $250 \mathrm{mM} \mathrm{NaCl}, 25 \mathrm{mM}$ EDTA, $0.5 \%$ SDS) added. The extract was centrifuged and the supernatant recovered. RNase A was adjusted to $0.1 \mathrm{mg} / \mathrm{ml}$ and the solution incubated at $65^{\circ} \mathrm{C}$ for $30 \mathrm{~min}$. DNA was precipitated with isopropanol, centrifuged and finally dissolved in $100 \mu \mathrm{l}$ of TE.

\section{DNA amplification}

All oligonucleotide primers were random 10- or 11-mers synthesized on an Applied Biosystems 392 DNA/RNA Synthesizer, precipitated with ethanol and dissolved in sterile distilled water. The PCR was carried out in a $50 \mu \mathrm{l}$ volume containing $1 \mathrm{U}$ of 
Taq polymerase (Boehringer-Mannheim), buffer supplied by the manufacturer $(10 \mathrm{mM}$ Tris- $\mathrm{HCl}$, $1.5 \mathrm{mM} \mathrm{MgCl} 2,50 \mathrm{mM} \mathrm{KCl}, 1 \mathrm{mg} / \mathrm{ml}$ of gelatine, $\mathrm{pH} 8.3), 100 \mu \mathrm{M}$ of each dNTP, approximately $400 \mathrm{nM}$ primer, $0.05 \%$ TritonX-100 and either $0.25 \mu \mathrm{l}$ of large-scale (150 - $450 \mathrm{ng}$ ) or $2.5 \mu \mathrm{l}$ of small-scale (50 - $150 \mathrm{ng}$ ) isolated DNA. The PCR was performed in a Techne PHC2 thermal cycler and consisted of 35 to 40 cycles of $30 \mathrm{sec}$ at $95^{\circ} \mathrm{C}$, $30 \mathrm{sec}$ at $35^{\circ} \mathrm{C}$ and $1 \mathrm{~min} 10 \mathrm{sec}$ at $72^{\circ} \mathrm{C}$ after the initial denaturation step of $3 \mathrm{~min} 30 \mathrm{sec}$ at $95^{\circ} \mathrm{C}$. A different PCR program (the first three cycles consisted of $40 \mathrm{sec}$ at $95^{\circ} \mathrm{C}, 40 \mathrm{sec}$ at $37^{\circ} \mathrm{C}$ and $50 \mathrm{sec}$ at $71^{\circ} \mathrm{C}$ followed by $32-35$ cycles as above) was also tested, because it has been reported that higher annealing temperature and shorter extension time during the first cycles improve the specificity and the yield (RUANO et al. 1991). Samples of $20 \mu \mathrm{l}$ were run on $1.2 \%$ agarose gel at $40 \mathrm{~V}$ overnight in the presence of ethidium bromide. A $1 \mathrm{~kb}$ DNA ladder (BRL) was used as a molecular weight marker. The gels were photographed under UV light using Polaroid film 665 or 667.

The combined DNA samples from the greenhouse-grown plants of 'Valtti', 'Kova' and 'Kulta' were analyzed with 34 RAPD primers (Table 1). Three primers $(19,68,74)$ were tested on about 50 individual DNA samples of each of these cultivars and five primers $(19,58,68,74,113)$ on ten additional cultivars or lines.

\section{Results and discussion}

Parameters affecting the RAPD assay were tested with primers 19 and 68 . First, the reproducibility of RAPD patterns was studied by repeating the PCR three to five times under the same amplification conditions. Strong fragments were found to be highly reproducible even with different PCR programs: with varying number of cycles (35-40) or slight changes in times and temperatures. No differences in specificity or yield were found when using a PCR program with a higher annealing temperature and a shorter extension time during the first three cycles. However, both the quantity (Fig. 1)
Table 1. Nucleotide sequences of the primers.

\begin{tabular}{llcl}
\hline $\begin{array}{l}\text { Primer } \\
\text { number }\end{array}$ & $\begin{array}{l}\text { Sequence } \\
\left(5^{\prime}-3^{\prime}\right)\end{array}$ & $\begin{array}{l}\text { Primer } \\
\text { number }\end{array}$ & $\begin{array}{l}\text { Sequence } \\
\left(5^{\prime}-3^{\prime}\right)\end{array}$ \\
\hline 10 & GCTGCTCGAGT & 76 & ATCGTCGATGC \\
14 & GCACTGTCGAC & 78 & AGTCGACTTC \\
19 & CGCTCTAGACC & 79 & GCACTGAGTA \\
25 & GCGTGTAGGCT & 110 & ACGCCGTACG \\
26 & GGAATCTCGGT & 111 & TCGGAAGGAC \\
33 & CCGCTTAGTTC & 112 & GGACACTACT \\
58 & CTTGACGCTGA & 113 & AACCGCGGTCT \\
61 & ATGGCTCAGTG & 114 & CTTGCTACCCG \\
62 & CGTAGCATCT & 115 & TCGAGCCTGGG \\
64 & GACGTGCAATG & 116 & GTAGCGATTCC \\
65 & ACGTGCATGG & 117 & GCGCAAGTGAA \\
67 & TGCGACCATGG & 118 & TTCGAGCAGG \\
68 & CGGCTTGCTCG & 119 & AAGCCTCACC \\
69 & TACCTGCCATC & 120 & GCCGAATACT \\
73 & ACGTACGTGAC & 121 & TCGGTCATCC \\
74 & GCTGACTCGAG & 122 & CACCGCTACT \\
75 & CGAACCTGATC & 123 & ACTGAGCGTG \\
\hline
\end{tabular}

and quality (Fig. 2) of the template DNA affected the RAPD profile.

The effect of varying amounts of template DNA on the RAPD patterns was tested by using $5 \mathrm{pg}$ 600 ng of DNA extracted by the Dellaporta method. The effect depends on the primer and no conclusions can be drawn regarding the size and number of fragments amplified with different amounts of template. Fragments can disappear ( $\mathrm{a}$ and $\mathrm{b}$ in Fig. 1) or appear (c, e and g in Fig. 1) with increasing template/primer ratio, and the intensity of the fragments is variable ( $f$ and $d$ in Fig. 1). Nevertheless, the RAPD patterns are consistent with template DNA concentrations ranging from $1 \mathrm{ng}$ to $75 \mathrm{ng}$ per $50 \mu \mathrm{l}$ reaction with $400 \mathrm{nM}$ primer. Similar results have been obtained in cauliflower (BOURY et al. 1992) with DNA concentrations ranging from $12.5 \mathrm{ng}$ to $75 \mathrm{ng}$ (lower or higher concentrations were not tested). Recently, DEVOS and GALE (1992) reported that within the range of $100 \mathrm{pg}-100 \mathrm{ng}$ only $10-20 \mathrm{ng}$ of template DNA with $200 \mathrm{nM}$ primer yielded reproducible patterns in wheat. Furthermore, the reaction conditions had to be rigorously optimized. These discrepancies from our results are probably due to differences in the genome sizes and complexities of turnip rape 


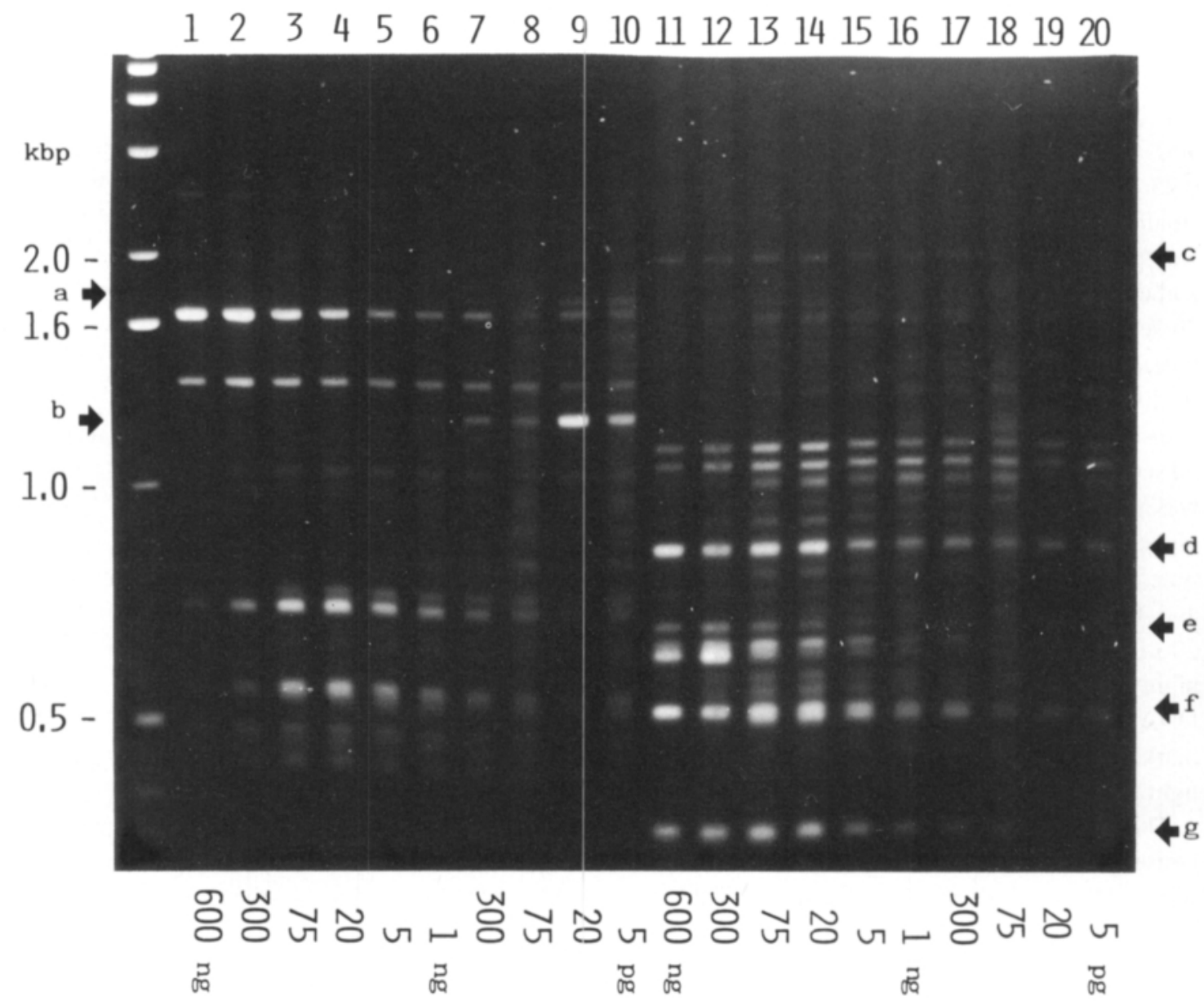

Fig. 1. RAPD profiles generated with a dilution series of template DNA (one individual). Lanes 1-10, primer 68; lanes 11-20, primer 19. Arrows ( $\mathrm{a}-\mathrm{g}$ ) indicate differences in the patterns (fragment intensity, fragment appearance). The RAPD patterns look similar, with DNA concentrations ranging from $1 \mathrm{ng}$ to $75 \mathrm{ng}$ per $400 \mathrm{nM}$ primer in a $50 \mu \mathrm{l} \mathrm{PCR}$.

and wheat (wheat has a large genome rich in repetitive DNA). In RAPD analysis of Brassica genomes the DNA concentration is apparently not so critical.

Because the large-scale DNA extraction method is quite time-consuming, we tested the Edwards method which enables extraction of small amounts of impure plant genomic DNA in $15 \mathrm{~min}$ (the RNase treatment can be omitted) without having to handle hazardous organic solvents. However, the DNA concentration obtained with the Edwards method is remarkably lower than with the Dellaporta method. The RAPD patterns from DNAs extracted with the two methods showed differences only in the intensity of some fragments (Fig. 2). Hence the rapid Edwards method is a suitable DNA extraction method for RAPD use. However, it is preferable that all the template DNAs in one study are extracted by the same procedure.

We also wanted to minimize the experimental input required for possible cultivar identification with RAPD markers. In the case of RAPDs, all fragments amplifiable from a certain population could be taken as one measure of its identity. Considering an outbreeding cultivar population, it is necessary to analyze several plants to get a concep- 


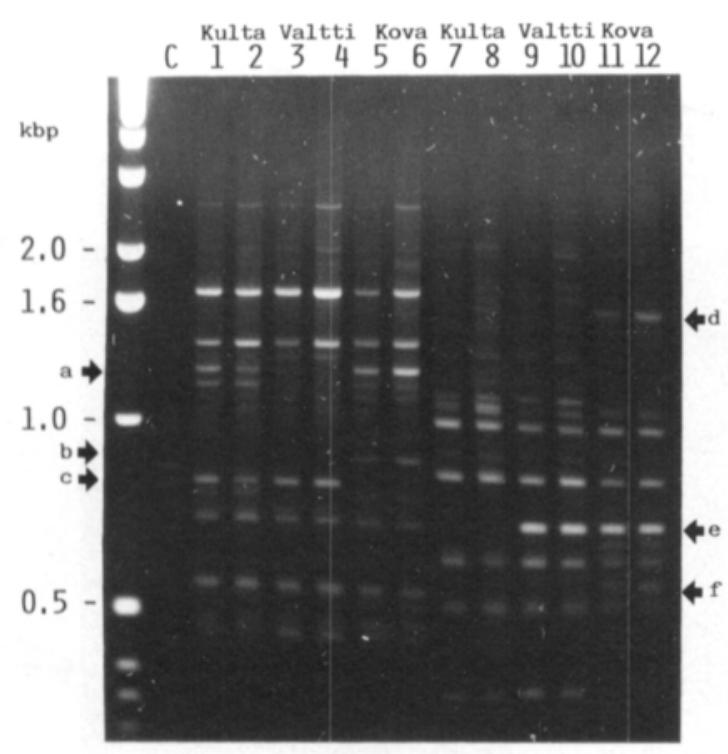

Fig. 2. Comparison of different extraction methods. The RAPD patterns are from $75 \mathrm{ng}$ DNA of combined samples (= ten individuals) of three turnip rape cultivars ('Kulta', 'Valtti', 'Kova') extracted with either the Edwards (lanes 1, $3,5,7,9,11$ ) or the Dellaporta method (lanes 2, 4, 6, 8, 10 , 12) and amplified with two different primers (lanes 1-6, primer 68 ; lanes $7-12$, primer 19). Lane $C$ is the negative control with no genomic DNA. There are differences only in the intensity of some fragments in the RAPD patterns extracted with the two methods. Arrows (a-f) indicate polymorphic fragments.

tion of the variation present. To make the task less laborious, we studied the possibility to use DNA from combined samples of ten individuals. The RAPD profiles from combined samples showed most of the fragments generated from the ten respective individual samples. Very strong fragments were amplified even when they were represented only in one individual out of ten, whereas some faint fragments were consistently not amplified when present in three to five individual samples.

We then tested the combined samples of 'Valtti', 'Kova' and 'Kulta' with 34 RAPD primers to find putative polymorphic RAPD loci. Of the 213 scorable fragments, $22 \%$ were found to be polymorphic in these samples. Twenty primers detected differences between 'Valtti' and 'Kova'; 9 primers were able to separate the three cultivars. Analysis of ten more cultivars or lines of turnip rape (e.g. primer 68 in Fig. 3) did not reveal many additional polymorphic RAPD loci. This discloses that more than one RAPD marker must be used parallelly if a multitude of cultivars are to be distinguished.

To test how well a combined sample reflects the variation in a population, more individuals of cultivars 'Valtti', 'Kova' and 'Kulta' were analyzed with three primers. It turned out that most of the fragments which were characteristic of one cultivar in the initial (combined) samples were amplified also from the other cultivars when additional individuals were studied, thus exhibiting only frequency differences between cultivars. Therefore, it is preferable to use e.g. five different combined samples of ten individuals (increasing the amount of individuals in a combined sample may reduce the ability to resolve the presence of rare markers).

The percentage of individuals showing the visible allele at a RAPD locus varied from 0 to $84 \%$ (Table 2). The visible allele often occured less frequently in each population sample than the invisible one(s). For two marker loci (68 a and c) the invisible allele(s) was monomorphic in one of the populations. In such situations, the absence of a RAPD fragment might be used as a cultivar-specific marker.

Because of wide variability among individuals, cultivar identification of outbreeding species is mostly based on differences in allele frequencies, e.g. in isozymes (HAYWARD and McADAM 1977, NIELSEN et al. 1985). According to our study, also the RAPD method is suitable for this kind of cultivar identification in Brassica rapa ssp. oleifera. Further, it is possible to find cultivar-specific RAPD markers (presence vs. absence of fragments). This requires screening of cultivars with several primers, which is, however, fast and easy. The feasibility of the RAPD method can further be improved by the use of the rapid Edwards DNA extraction method and combined samples, which ease the scoring of the amplifiable fragments from each population. Our study also indicates that the amount of RAPD polymorphism in spring turnip rape is adequate for the purpose of gene mapping. 


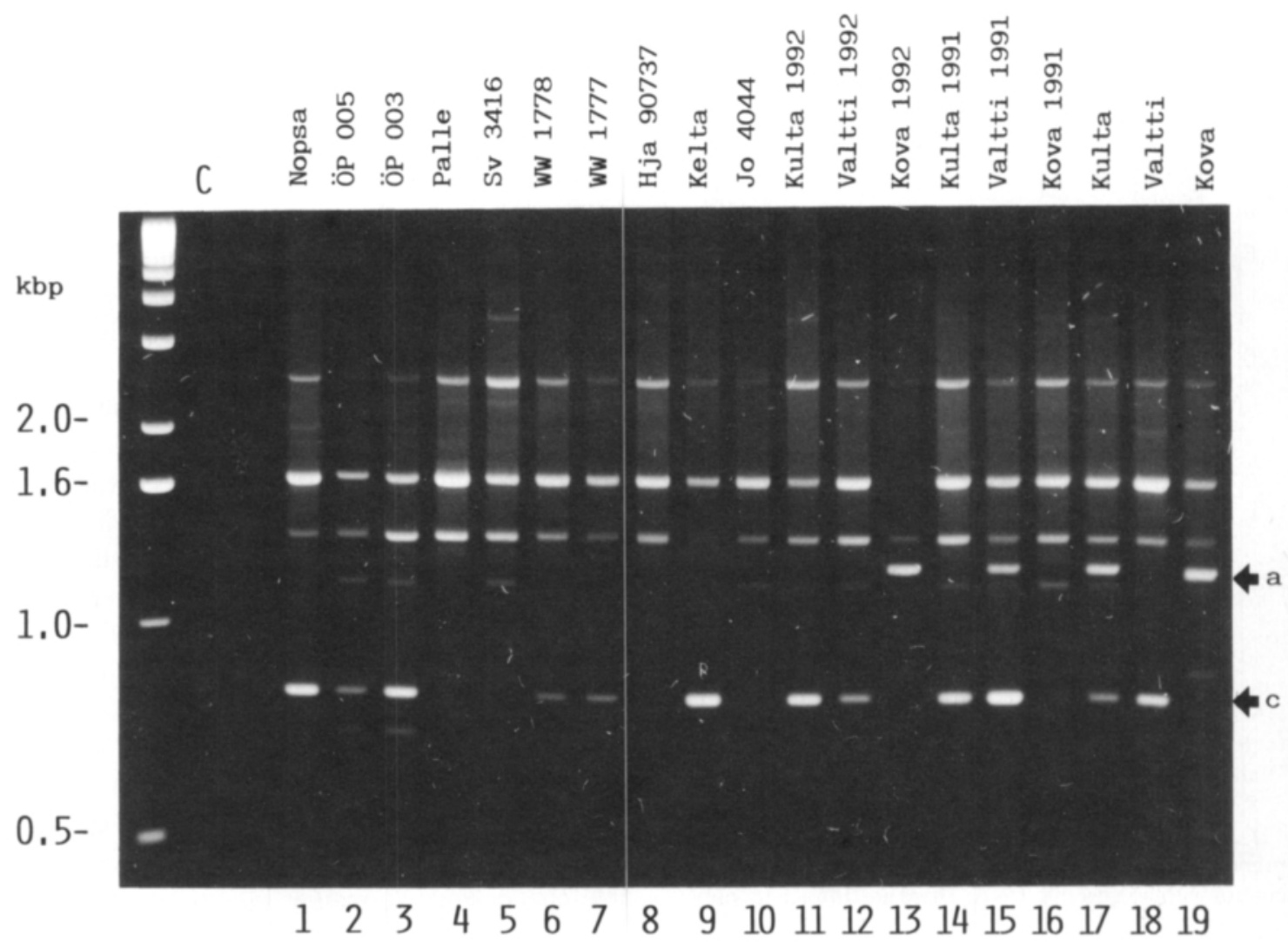

Fig. 3. RAPD patterns from the combined samples (= ten individuals) of thirteen different cultivars or breeding lines of spring turnip rape produced by primer 68. DNA was extracted from plants grown either in field trials in 1992 (lanes 1-13) and 1991 (lanes 14-16), or in the greenhouse from an earlier seed lot (lanes 17-19). Arrows indicate polymorphic fragments (same as in Fig. 2). The discrepancy seen between the greenhouse-grown and field samples for one fragment (a) may reflect frequency changes during successive generations (or mixing of individuals).

Table 2. Percentage of individuals showing a visible allele at five RAPD loci in the cultivars 'Valtti', 'Kova' and 'Kulta'.

\begin{tabular}{|c|c|c|c|c|}
\hline \multirow[b]{2}{*}{ Primer } & \multicolumn{4}{|c|}{$\%$ of cultivar sample } \\
\hline & $\begin{array}{l}\text { Fragment/size } \\
\qquad(k b)\end{array}$ & $\begin{array}{c}\text { 'Valtti' } \\
n=43-46\end{array}$ & $\begin{array}{c}\text { 'Kova' } \\
\mathrm{n}=43-45\end{array}$ & $\begin{array}{c}\text { 'Kulta' } \\
\mathrm{n}=43-51\end{array}$ \\
\hline $19^{a}$ & e $(0.7)$ & 48 & 36 & 30 \\
\hline $68^{\mathrm{a}}$ & $\begin{array}{ll}\text { a } & (1.2) \\
\text { c } & (0.8)\end{array}$ & 19 & $\begin{array}{l}7 \\
-\end{array}$ & $\begin{array}{r}8 \\
10\end{array}$ \\
\hline 74 & $\begin{array}{ll}\mathrm{g} & (1.1) \\
\mathrm{h} & (0.9)\end{array}$ & $\begin{array}{l}84 \\
49\end{array}$ & $\begin{array}{r}12 \\
7\end{array}$ & $\begin{array}{l}42 \\
30\end{array}$ \\
\hline
\end{tabular}

\footnotetext{
${ }^{\text {a }}$ Fragments are the same as in Fig. 2.

$\mathrm{n}=$ number of individuals which gave a scorable RAPD pattern.
} 
Acknowledgements. We are grateful to Ms. Marja-Riitta Mäkelä for skillful technical assistance. This study was sup- ported by the Ministry of Agriculture and Forestry in Finland.

\section{References}

Arus, P., Tanksley, S.D., Orton, T.J. \& Jones, R.A. 1982. Electrophoretic variation as a tool for determining seed purity and for breeding hybrid varieties of Brassica oleracea. Euphytica 31: 417-428.

Boury, S., Gavalda, M.-C., Lutz, I., Guidet, F. \& SCHLesser, A. 1992. Genetic fingerprints of cauliflower with RAPD markers and their use to determine the rate of inbreds in a set of seeds supposed to be F1 hybrid. Eucarpia XIII Congr. Angers, France. p. 611-612.

Dellaporta, S.L., Wood, J. \& Hicks, J.B. 1983. A plant minipreparation: version II. Plant Mol. Biol. Rep. 1: 1921.

Devos, K.M. \& GALE, M.D. 1992. The use of random amplified polymorphic DNA markers in wheat. Theor. Appl. Genet. 84: 567-572.

Edwards, K., Johnstone, C. \& Thompson, C. 1991. A simple and rapid method for the preparation of plant genomic DNA for PCR analysis. Nucleic Acids Res. 19: 1349.

GuptA, S.K. \& RöвBEL.EN, G. 1986. Identification of rapeseed (Brassica napus) cultivars by electrophoresis. Plant Breeding 96: 363-370.

HaYWARD, M.D. \& McAdam, N.J. 1977. Isozyme polymorphism as a measure of distinctiveness and stability in cultivars of Lolium perenne. Z. Pflanzenzüchtg. 79: 5968.

He, S., Онм, H. \& MacKenzie, S. 1992. Detection of DNA sequence polymorphisms among wheat varieties. Theor. Appl. Genet. 84: 573-578.

Hu, J. \& Quiros, C.F. 1991. Identification of broccoli and cauliflower cultivars with RAPD markers. Plant Cell Reports 10: 505-511.

Koller, B., Lehmann, A., McDermott, J.M. \& Gessler, C. 1993. Identification of apple cultivars using RAPD markers. Theor. Appl. Genet. 85: 901-904.

Kresovich, S., Williams, J.G.K., McFerson, J.R., Routman, E.J. \& SCHAAL, B.A. 1992. Characterization of genetic identities and relationships of Brassica oleracea L. via random amplified polymorphic DNA assay. Theor. Appl. Genet. 85: 190-196.

Nielsen, G., Ostergand, H. \& Johansen, H. 1985. Cultivar identification by means of isoenzymes. II. Genetic variation at four enzyme loci in diploid ryegrass. Z. Pflanzenzüchtg. 94: 74-86.
Quiros, C.F., Hu, J., This, P., Chevre, A.M. \& Delseny, M. 1991. Development and chromosomal localization of genome-specific markers by polymerase chain reaction in Brassica. Theor. Appl. Genet. 82: 627-632.

Roininen, J., Nissilä, E., Puolimatka, M. \& Pulli, S. 1992. Identification of barley cultivars using SDS-PAGE electrophoresis. Agric. Sci. Finl. 1: 73-82.

Ruano, G., Brash, D.E. \& KidD, K.K. 1991. PCR: The first few cycles. Perkin Elmer Cetus: Amplifications - A forum for PCR users 7: 1-4.

Tinker, N.A., Fortin, M.G. \& MAther, D.E. 1993. Random amplified polymorphic DNA and pedigree relationships in spring barley. Theor. Appl. Genet. 85: 976-984.

Welsh, J. \& McClelland, M. 1990. Fingerprinting genomes using PCR with arbitrary primers. Nucleic Acids Res. 18: 7213-7218.

Williams, J.G.K., Kubelik, A.R., LiVAK, K.J., RaFAlski, J.A. \& TingeY, S.V. 1990. DNA polymorphisms amplified by arbitrary primers are useful as genetic markers. Nucleic Acids Res. 18: 6531-6535.

Xu, Y., Clark, M.S. \& PehU, E. 1993. Use of RAPD markers to screen somatic hybrids between Solanum tuberosum and S. brevidens. Plant Cell Reports 12: 107-109.

\section{Manuscript received April 1993}

Pirjo Tanhuanpää

Johanna Vilkki

Juha Vilkki

Seppo Pulli

Agricultural Research Centre of Finland

Institute of Plant Breeding

FIN-31600 Jokioinen, Finland

Johanna Vilkki

Present address:

Agricultural Research Centre of Finland

Institute of Animal Production

Animal Breeding

FIN-31600 Jokioinen, Finland 


\title{
SELOSTUS
}

\section{Kevätrypsin RAPD-lokusten polymorfia}

\section{Pirjo TanhuanPäÄ, Johanna VilkKi, Juha VilkKi ja SePPo PUlli}

\author{
Maatalouden tutkimuskeskus
}

DNA:n muuntelua voidaan tutkia RAPD-menetelmällä (Random Amplified Polymorphic DNA), joka perustuu satunnaisten DNA-jaksojen monistamiseen polymeraasiketjureaktiossa (PCR). Monistuvien jaksojen lukumäärä ja koko riippuvat PCR:ssä käytetyn alukkeen (= oligonukleotidi) ja tutkittavan DNA:n yhteensopivuudesta. Polymorfisia RAPD-lokuksia voidaan käyttää markkereina.

Tässä tutkimuksessa perehdyttiin RAPD-menetelmän käyttöedellytyksiin ja RAPD-lokusten polymorfiaan ristisiittoisella viljelykasvilla, kevätrypsillä. RAPD-kuvioiden tois- tettavuus oli hyvä, kun käytettiin suunnilleen samansuuruisia määriä tasalaatuisia DNA-näytteitä. Lajikkeiden välillä oli yleensä eroja vain polymorfisten lokusten alleelifrekvensseissä. Kuitenkin tutkimuksessa löytyi myös DNA-jaksoja, joita ei kaikista lajikkeista monistu lainkaan. Tällaisia lokuksia voitaisiin hyödyntää lajiketunnistuksessa. Kun käytetään nopeaa DNA:n eristystapaa ja yhdistettyjä (kymmenestä eri kasvista) DNA-näytteitä, RAPD-menetelmän käyttökelpoisuus lajiketunnistuksessa paranee. 